\title{
PERAN NOTARIS DALAM PERJANJIAN WARALABA ANTARA PT POS INDONESIA (PERSERO) PATI DENGAN BADAN USAHA PERSEORANGAN
}

\author{
Rifki Ardhianto*, Lathifah Hanim** \\ * Mahasiswa Program Magister (S2) Kenotariatan Fakultas Hukum UNISSULA, Semarang \\ ** Dosen Fakultas Hukum UNISSULA, Semarang, email: lathifah@unissula.ac.id
}

\section{ABSTRACT}

This study aims to determine the implementation and analyze the role of notary in a franchise agreement between PT Pos Indonesia (Persero) Pati with individual business entities, obstacles and solutions in the implementation of franchise agreement between PT Pos Indonesia (Persero) Pati with individual business entities and legal effects if the agreement A franchise between PT Pos Indonesia (Persero) Pati and individual business entities are not made by notarial deed.

Method This research is empirical law research method, that is research based on implementation in effort to get primary data preceded by library research to get secondary data. The research was conducted at PT Pos Indonesia (Persero) Pati, and the overall data obtained was analyzed qualitatively.

The results showed that the implementation and analysis of the role of notary in a franchise agreement between PT Pos Indonesia (Persero) Pati and individual business entities are agreements that are not contradictory to the law, religion, public order and morality. This means that the franchise agreement is valid and therefore the agreement becomes a law for those who make it, and binds both parties and the agreement is a standard reciprocal agreement because each party has equal rights and obligations put forward the principle of win-win solution Which are mutually beneficial. The obstacles that exist are the frenchisee can do wanprestasi which result in frenchisor loss. The solution is a franchisee before deciding to franchise must adjust to the franchise recipient character.

Against the legal consequences that arise as a transaction that breeds the agreement, the franchise invariably involves two parties with independent interests and sometimes opposites. The principle of profit maximization is also essentially a source of differences in interests and disputes that can occur between the two parties. This great advantage can only be achieved by both parties if both parties can establish a mutually beneficial synergism.

Keywords: Notary, Franchise Agreement, Individual Business Agency

\section{PENDAHULUAN}

Perkembangan di sektor ekonomi merupakan bagian yang penting untuk mencapai tujuan pembangunan bangsa, walaupun belum melakukan perubahan secara mendasar dalam sistem perekonomian, Indonesia telah membuktikan bangkitnya dari keterpurukan pasca krisis moneter tahun 1998. Hal ini dapat dilihat dari terus tumbuhnya para investor lokal dan asing untuk beriventasi di Indonesia serta berkembangnya pasar modal di Indonesia.

Pembangunan perekonomian bangsa didasarkan kepada demokrasi perekonomian, yang menentukan bahwa masyarakat harus memegang peranan aktif dalam kegiatan pembangunan ekonomi bangsa.
Menurut Pasal 33 Ayat (1) sampai Ayat (4) UndangUndang Dasar 1945 Amandemen ke IV, demokrasi perekonomian nasional memiliki ciri-ciri :

1. Perekonomian disusun sebagai usaha bersama berdasar atas asas kekeluargaan.

2. Cabang-cabang produksi yang penting bagi negara dan yang menguasai hajat hidup orang banyak dikuasai oleh negara.

3. Bumi air dan kekayaan alam yang terkandung didalamnya dikuasai oleh negara dan dipergunakan untuk sebesar-besar kemakmuran rakyat.

4. Perekonomian nasional diselenggarakan berdasarkan atas demokrasi ekonomi dengan prinsip kebersamaan, efisiensi berkeadilan, berkelanjutan, berwawasan lingkungan, kemandirian, serta dengan menjaga keseimbangan kemajuan dan 
kesatuan ekonomi nasional.

Upaya-upaya yang dilakukan untuk mencapai tujuan pembangunan ekonomi bangsa sangat membutuhkan usaha dan dana besar. Kehadiran Waralaba (Franchise) adalah salah satu upaya dalam mencapai pembangunan ekonomi. Hadirnya waralaba mengambil peranan yang dapat mendukung dalam pembangunan ekonomi dan sosial. Esensinya adalah telah menciptakan lapangan pekerjaan, meningkatkan kesejahteraan masyarakat, dan dapat menciptakan stabilitas ekonomi bangsa.

Kepemilikan agenpos oleh franchisee dapat dilakukan oleh badan usaha perorangan. Badan usaha perorangan atau disebut perusahaan perseorangan adalah perusahaan yang dimiliki, dikelola, dan dikendalikan oleh satu orang pemilik. Menurut Murti Sumarni dan Jhon Suprianto dalam bukunya yang berjudul Dasar-Dasar Ekonomi Perusahaan, Perusahaan perseorangan adalah perusahaan yang dimiliki, dikelola, dan dipimpin oleh seseorang yang bertanggung jawab penuh terhadap semua resiko dan aktivitas perusahaan. Perusahaan perseorangan banyak sekali dipakai di Indonesia. Bentuk perusahaan ini biasanya dipakai untuk kegiatan usaha kecil, atau pada saat permulaan mengadakan kegiatan usaha, misalnya dalam bentuk toko, restaurant, bengkel, dan lain-lain. Walaupun jumlah perusahaan yang ada relatif banyak, tetapi volume penjualan masing-masing relatif kecil jika dibandingkan perusahaan lain. Untuk pendirian perusahaan perseorangan, izin yang dikenakan secara relatif dapat dikatakan lebih ringan dan sederhana persyaratannya dibandingkan dengan jenis perusahaan lainnya. Selama ini pemerintah tidak menentukan suatu kategori khusus tentang bentuk usaha ini, jadi tidak ada pemisahan secara hukum antara perusahaan dan kepentingan pribadi.

Pada masa sekarang ini pemerintah lebih memperhatikan pengimbangan usaha perusahaanperusahaan kecil sebagai salah satu strategi pembangunan. Perusahaan-perusahaan kecil dari perusahaan perseorangan ini dapat bekerja sama dengan pemilik merek waralaba (franchisor) dalam membangun usaha waralaba.

Pembentukan usaha waralaba akan berkaitan dengan notaris. Notaris berperan dalam membantu menciptakan kepastian dan perlindungan hukum bagi masyarakat. Notaris sebagai pejabat umum berwenang untuk membuat akta otentik, sejauh pembuatan akta otentik tersebut tidak dikhususkan bagi pejabat umum lainnya. Kepastian dan perlindungan hukum itu tampak melalui akta otentik yang dibuatnya sebagai alat bukti yang sempurna di Pengadilan. Alat bukti sempurna karena akta otentik memiliki tiga kekuatan pembuktian yaitu kekuatan pembuktian lahiriah (uitwendige bewijsracht), kekuatan pembuktian formal (formele bewijskracht) dan kekuatan pembuktian material (materiele bewijskracht). ${ }^{1}$

Pada dasarnya bentuk dari suatu akta bukan suatu masalah, apakah itu akta dibawah tangan atau akta otentik yang dibuat oleh atau dihadapan Notaris, selama para pihak tetap berkomitmen untuk melaksanakan kewajiban dan hak yang tertuang dalam akta tersebut. ${ }^{2}$ Akan menjadi suatu problem tersendiri bagi para pihak bila nantinya salah satu pihak yang bersepakat mengingkari kesepakatan dan lahirlah suatu sengketa yang bisa merugikan banyak pihak. Risiko tersebut dapat terjadi karena adanya perbedaan kepentingan tiap individu, ketidakjelasan identitas dan pengingkaran suatu prestasi yang akhirnya berujung pada konflik antara individu. ${ }^{3}$ Oleh karena itu, menjadi penting bagi individu tersebut untuk melengkapi diri dengan surat atau dokumen yang dapat melindunginya dari segala hubungan hukum, oleh sebab pilihan akta otentik dirasa sebagai suatu hal yang tepat dalam menuangkan dan pengesahan suatu kesepakatan.

Notaris sebagai pejabat umum dapat memberikan jaminan serta perlindungan hukum melalui formulasi akta otentik yang dibuatnya. Akta merupakan refleksi dari pemenuhan serta pelaksanaan hak dan kewajiban antara suatu subjek hukum dengan subjek hukum lainnya. Menurut R. Subekti bahwa "dari suatu perkara perdata alat bukti (alat pembuktian) yang utama adalah tulisan,

${ }^{1}$ G. H. S. Lumban Tobing, Peraturan Jabatan Notaris, cet. V, (Jakarta: Gelora Aksara Pratama, 1999), h. 55-59.

${ }^{2}$ R. Subekti berpendapat "Suatu akte ialah suatu tulisan yang memang dengan sengaja dibuat untuk dijadikan bukti tentang suatu peristiwa dan ditandatangani, dengan demikian unsur penting untuk suatu akte adalah kesengajaan untuk menciptakan suatu bukti tertulis dan penandatanganan tulisan itu". Lihat R. Subekti, Hukum Pembuktian, cet. XVI, (Jakarta: Padya Paramita, 2007), h. 25.

${ }^{3}$ Ira Koesoemawati dan Yunirman Rijan, Kenotaris, cet. I, (Jakarta: Raih Asa Sukses, 2009), h. 6. 
sedangkan dalam suatu perkara pidana kesaksian". ${ }^{4}$

Pelaksanaan perjanjian waralaba antara perusahaan perseorangan dengan dengan pemilik waralaba dalam hal ini PT Pos Indonesia (Persero) Pati harus diatur sedemikian rupa agar para pihak dapat mengetahui secara pasti ketentuan-ketentuan yang telah disepakati. Hal inilah yang mendasari penulis untuk menulis dengan judul "Peran Notaris Dalam Perjanjian Waralaba Antara PT Pos Indonesia (Persero) Pati Dengan Badan Usaha Perseorangan".

\section{PEMBAHASAN}

\section{Peran Notaris dalam Perjanjian Waralaba antara PT Pos Indonesia (Persero) Pati dengan Badan Usaha Perseorangan}

Dalam kontrak waralaba PT. Pos Indonesia (Persero) Pati berbentuk single unit/unit tunggal PT. Pos Indonesia (Persero) Pati tapi dimungkinkan kontrak baru untuk single unit PT. Pos di tempat tempat lain. Artinya pewaralaba memberikan hak kepada terwaralaba untuk menjalankan usaha atas nama usahanya, dengan panduan prosedur yang telah ditetapkan sebelumnya. Terwaralaba hanya diperkenankan untuk menjalankan usahanya pada sebuah cabang / unit yang telah disepakati. Pihak manajemen tidak membantu dalam urusan pencarian modal bagi penerima waralaba PT. Pos Indonesia (Persero) Pati tapi pihak manajemen sendiri membantu menegosiasikan untuk masalah tempat dan lebih memilih dengan sistem sewa, sedangkan untuk promosi atau iklan pihak manajemen memberikan keleluasaan bagi penerima waralaba PT. Pos Indonesia (Persero) Pati dalam melakukan pengenalan outletnya kepada masyarakat umum.

Waktu yang dibutuhkan untuk memproses PT. Pos Indonesia (Persero) Pati sampai tahap soft opening kurang lebih $2-3$ bulan setelah lokasi diperoleh dan dipastikan. Selanjutnya dibuatlah franchisee agreement atau perjanjian waralaba sebagai tindak lanjut dari MOU yang telah dibuat berdasarkan kesepakatan bersama. Perjanjian waralaba (franchise agreement) adalah kumpulan

\footnotetext{
${ }^{4}$ Pendapat R. Subekti didasarkan Pasal 1866 Kitab UndangUndang Hukum Perdata dan 164 RIB (Pasal 283 RDS) tentang alat-alat bukti dalam perkara perdata meliputi: bukti tertulis, bukti dengan saksi-saksi, persangkaanpersangkaan, pengakuan dan sumpah. Lihat Ibid., h. 19.
}

persyaratan, ketentuan dan komitmen yang dibuat yang dikehendaki oleh franchisor bagi para franchiseenya di dalam perjanjian waralaba ini tercantum ketentuan yang berkaitan dengan hak dan kewajiban franchisee dan franchisor, misalnya hak teritorial yang dimiliki franchisee persyaratan lokasi, ketentuan pelatihan, biaya-biaya yang harus dibayarkan oleh franchisee kepada franchisor, ketentuan berkaitan dengan lama pemberian waralaba dan perpanjangannya dan ketentuan lain yang mengatur hubungan fanchisee dan franchisor.

Dapat dikemukakan bahwa paket investasi awal untuk wilayah Pati dibutuhkan modal sebesar Rp 50.000 .000 (lima puluh juta rupiah). Untuk wilayah yang lain tergantung dari biaya sewa lokasi dan tingkat kemahalan daerah dimana akan didirikan gerai PT. Pos Indonesia (Persero). Investasi tersebut digunakan sebagai modal untuk sewa bangunan, perijinan, dan perlengkapan berupa meubeler, signase, eksterior, sistem informasi/ IT, modal kerja (3 bulan), inventaris gerai (sepeda motor, AC, TV, genset, PABX, alat tulis, dan lain-lain),

Dalam format bisnis waralaba, paradigma yang menyatakan bahwa memiliki bisnis sendiri berarti memiliki kebebasan dalam mengaktualisasikan diri mengelola bisnis tersebut adalah tidak benar. Demikian halnya yang berlaku dalam bisnis waralaba agenpos PT. Pos Indonesia (Persero) Pati, jika ingin membeli hak waralaba walaupun itu pemilik sekalipun harus tetap tunduk dengan mengikuti seluruh prosedur/ aturan main yang dibeli hak usahanya yang telah memiliki identitas legal baik secara lengkap dengan perangkat kerasnya atau terbatas pada penggunaan sistem dan identitasnya. Ini merupakan aspek penting baik pengusaha waralaba maupun mitra usaha penerima waralaba yaitu masalah kepastian dan perlindungan hukumnya. Banyak franchisee gagal dalam mengembangkan konsep bisnisnya karena tidak paham dengan karakter bisnis format waralaba itu sendiri.

Dapat dijelaskan, penerima waralaba harus menjalankan usahanya sendiri dengan mempergunakan merek dagang atau merek jasa serta dengan memanfaatkan metode dan tata cara atau prosedur yang telah ditetapkan oleh pemberi waralaba. Kewajiban untuk mempergunakan metode dan tata cara atau prosedur yang telah ditetapkan oleh 
pemberi waralaba oleh penerima waralaba membawa akibat lebih lanjut bahwa suatu usaha waralaba adalah usaha yang mandiri, yang tidak digabungkan dengan kegiatan usaha lainnya (milik penerima waralaba). Ini berarti pemberian waralaba menuntut eksklusivitas dan bahkan dalam banyak hal mewajibkan terjadinya non-competition cause bagi penerima waralaba, bahkan setelah perjanjian pemberian waralabanya berakhir.

Kewajiban pemberi waralaba adalah memberikan bantuan, fasilitas, bimbingan operasional, pelatihan, dan pemasaran yang diberikan pemberi waralaba serta memberikan segala macam informasi yang menjadi obyek waralaba.

Kewajiban penerima waralaba selain melakukan pendaftaran waralaba, berkewajiban untuk menjalankan kegiatan usaha sebagai mitra usaha pemberi waralaba menurut ketentuan dan tata cara yang diberikan pemberi waralaba, garis besarnya seperti pelatihan awal, operasional gerai, pembayaran tepat waktu termasuk royalty dalam bentuk, jenis dan jumlah yang telah disepakati, audit yaitu dengan memberikan laporan baik secara berkala maupun atas permintaan khusus dari pemberi waralaba, memberikan keleluasaan bagi pemberi waralaba untuk melakukan pengawasan maupun inspeksi berkala maupun secara tiba - tiba guna emastikan penerima waralaba telah melaksanakan waralaba dengan baik, membeli barang modal tertentu maupun barang lainnya dalam rangka pelaksanaan waralaba, menjaga kerahasiaan (trade secret) atas penemuan atau ciri khas usaha yang menjadi karakteristik khusus dimana rahasia dagang ini dapat berupa prosedur operasi, resep ataupun daftar pelanggan dan pemasok ataupun racikan rahasia yang merupakan elemen terpenting dalam setiap franchise, dan tidak perduli apapun bentuk franchise tersebut, dan atas pengakhiran waralaba untuk mengembalikan seluruh data, informasi, maupun keterangan yang diperolehnya, selanjutnya menyangkut kinerja, kepemilikan bisnis dan launching.

Hak pemberi waralab adalah melakukan pengawasan jalannya pelaksanan waralaba, memperoleh laporan secara berkala, mewajibkan untuk menjaga kerahasiaan atas penemuan atau ciri khas usaha, mewajibkan penerima waralaba tidak melakukan kegiatan yang sejenis, serupa ataupun secara langsung maupun tidak langsung dapat menimbulkan persaingan, menerima pembayaran royalty, sekanjutnya atas pengakhiran waralaba meminta penerima waralaba mengembalikan seluruh data, informasi maupun keterangan yang diperoleh.

Peneyelesaian sengketa ditempuh lewat jalur musyawarah dan mufakat, jika tidak bisa diupayakan lewat jalur musyawarah dapat dilakukan melalui forum pengadilan. Mengingat akan sifat dari pemberian waralaba khususnya format bisnis, penyelesaian perselisihan lewat forum pengadilan relatif tidak menguntungkan.

Selanjutnya untuk tata cara perpanjangan setelah masa perjanjian waralaba berakhir, franchisee dapat memperpanjang lagi perjanjian waralabanya berdasarkan :

a. Kinerja penerima waralaba mencapai target

b. Tidak ada pelanggaran oleh penerima hak waralaba terhadap perjanjian waralaba Unit PT. Pos Indonesia (Persero) Pati

c. Mengajukan permohonan perpanjangan hak waralaba paling lambat 3 bulan sebelum masa waralaba berakhir

d. Menandatangani perjanjian waralaba baru yang isinya dapat berbeda dari perjanjian waralaba yang semula, paling lambat 1 (satu) bulan sebelum akhir masa waralaba.

Sementara untuk pengakhiran dan pemutusan perjanjian, memiliki jangka waktu berlakunya dan berakhir dengan habisnya jangka waktu pemberian waralaba kecuali jika diperpanjang oleh para pihak. Bahwa pihak terhadap siapa suatu perikatan tidak dipenuhi dapat menuntut penggantian, kerugian dan bunga seperti yang tercantum dalam pasal $1267 \mathrm{KUH}$ Perdata Dalam perjanjian waralaba ini juga memuat pasal-pasal non kompetisi usaha yang tegas untuk mencegah penerima waralaba termasuk keluarga dekat dan karyawan serta perusahaan afiliasinya tidak akan membuka usaha yang mirip dan berpotensi menjadi pesaing usahanya dalam bidang industri serupa dengan dukungan langsung maupun tidak langsung dari penerima waralaba sepanjang masa waralaba.

Kendala-kendala Hambatan dan Solusi dalam Pelaksanaan Perjanjian Waralaba antara PT Pos Indonesia (Persero) Pati dengan Badan Usaha Perseorangan. 
Sebagai suatu transaksi yang melahirkan perjanjian, waralaba selalu melibatkan dua pihak. Kedua belah pihak tersebut memiliki kepentingan yang berdiri sendiri dan kadangkala bertolak belakang, meskipun secara konseptual dapat dikatakan bahwa kedua belah pihak tersebut, yaitu pemberi lisensi dan pemberi waralaba maupun penerima lisensi dan penerima waralaba, pasti akan mencari keuntungan yang sebesar-besarnya. Maksud untuk mencari keuntungan sebesarbesarnya ini jugalah yang pada pokoknya menjadi sumber perbedaan kepentingan dan perselisihan yang dapat terjadi di antara kedua belah pihak tersebut. Keuntungan yang besar ini hanya dapat dicapai oleh kedua belah pihak jika antar kedua belah pihak dapat menjalin sinergisme yang saling menguntungkan. Perjanjian waralaba ini merupakan bentuk perlindungan hukum yang diberikan kepada para pihak, dan perjanjian tersebut merupakan perjanjian baku timbal balik karena masing-masing pihak mempunyai hak dan kewajiban yang seimbang mengedepankan prinsip win-win solution yang saling menguntungkan.

Wanprestasi (kelalaian atau kealpaan) seorang debitur dapat berupa empat (4) macam yaitu:

1. Tidak melakukan apa yang disanggupi akan dilakukannya.

2. Melaksanakan apa yang dijanjikannya, tetapi tidak sebagaimana dijanjikan.

3. Melakukan apa yang dijanjikannya, tetapi terlambat.

4. Melakukan sesuatu yang menurut perjanjian tidak boleh dilakukan.

Kreditur dapat melakukan tuntutan kepada debitur yang telah melakukan wanprestasi dengan hal-hal sebagai berikut :

1. Kreditur dapat meminta pemenuhan prestasi saja pada debitur.

2. Kreditur dapat menuntut prestasi disertai ganti rugi kepada debitur (Pasal 1267 KUH Perdata).

3. Kreditur dapat menuntut dan meminta ganti rugi, hanya mungkin kerugian karena keterlambatan (HR 1 November 1918).

4. Kreditur dapat menuntut pembatalan perjanjian.

5. Kreditur dapat menuntut pembatalan disertai ganti rugi kepada debitur ganti rugi itu berupa pembayaran utang denda.

Akibat kelalaian kreditur yang dapat dipertanggungjawabkan yaitu:

1. Debitur berada dalam keadaan memaksa.

2. Beban beralih untuk kerugian kreditur, dan dengan demikian debitur hanya bertanggung jawab atas wanprestasi dalam hal ada kesengajaan atau kesalahan besar lainnya.

3. Kreditur tetap diwajibkan memberi prestasi balasan (Pasal 1602 KUH Perdata).

Berbagai kemungkinan yang bisa dituntut terhadap debitur yang lalai :

1. Kreditur dapat meminta pelaksanaan perjanjian, meskipun pelaksanaan sudah terlambat.

2. Kreditur dapat meminta penggantian kerugian saja, yaitu kerugian yang dideritanya karena perjanjian tidak atau terlambat dilaksanakan tetapi tidak sebagimana mestinya.

3. Kreditur dapat menuntut pelaksanaan perjanjian disertai dengan penggantian kerugian yang diderita olehnya sebagai akibat terlambatnya pelaksanaan perjanjian.

Dalam substansi kontrak pun telah mencantumkan berakhirnya kontrak berdasarkan pemutusan kontrak oleh salah satu pihak, apabila salah satu alasan saja tidak dipenuhi oleh pihak kedua (franchisee) maka sudah dianggap cukup oleh pihak pertama (franchisor) untuk melakukan pemutusan kontrak secara sepihak dan pihak pertama dapat menunjuk pihak lain atas kehendak dan berdasarkan pilihan sendiri untuk menyelesaikannya. Pihak kedua berkewajiban untuk menyerahkan seluruh data, informasi maupun keterangan yang diperolehnya. Ganti rugi dalam hal terjadi pemutusan perjanjian yang harus ditanggung franchisor ini, berlaku perlindungan hukum bagi pihak yang dirugikan seperti yang disebutkan dalam Pasal 1267 KUH Perdata yang berbunyi " bahwa pihak terhadap siapa suatu perikatan tidak dipenuhi dapat menuntut penggantian biaya, kerugian dan bunga".

Pemutusan kontrak secara sepihak ini dilakukan franchisor dengan berbagai pertimbangan dan keterpaksaan, karena pelanggaran yang dilakukan franchisee jelas akan mempengaruhi kinerja serta brand image di masyarakat yang telah sekian lama diperjuangkan franchisor. Selain itu sebenarnya pengusaha juga membutuhkan mitra kerja yang saling menguntungkan dan tanpa bantuan mitra tersebut tidak mungkin pengusaha mel aksanakan 
usahanya dengan baik. Hukum dalam menghadapi perubahan-perubahan sosial yang terjadi tidak senantiasa bereaksi dengan sanksinya, dan sesuai dengan fungsinya maka hukum baru bertindak apabila perubahan sosial itu menimbulkan konflik atau terjadi pelanggaran yang dapat mengganggu kelancaran produktifitas masyarakat.

\section{Akibat Hukum jika Perjanjian Waralaba antara PT Pos Indonesia (Persero) Pati dengan Badan Usaha Perseorangan tidak dibuat Akta Notariel}

Dalam dunia bisnis, seringkali ditemukan adanya akibat hukum yang dilakukan oleh para usahawan, akibat hukum dalam bisnis ini bagaimanapun juga harus diselesaikan dengan segera, agar bisnis yang dijalankan tidak mengalami kerugian besar. Dalam suatu transaksi bisnis, kontrak yang telah disepakati bersama / telah ditandatangani para pihak biasanya selalu disebutkan dalam suatu pasal tersendiri yang menyatakan cara bagaimana melakukan suatu penyelesaian atas suatu perselisihan atau sengketa yang timbul.

Permasalahan dalam kontrak waralaba sering terjadi ketika waralaba itu sudah berjalan. Hal ini memerlukan perhatian khusus, karena dasar sebuah waralaba adalah memberikan keuntungan bagi para pihak. Jika terjadi permasalahan maka yang menjadi rujukan pertama adalah isi dari klausul kontrak yang telah ditanda tangani oleh kedua belah pihak, yaitu pemberi waralaba dan penerima waralaba. Dari berbagai permasalahan yang timbul harus dicari jalan keluar yang terbaik agar didapatkan penyelesaian yang saling menguntungkan

Sengketa ini terjadi jika masing-masing pihak melakukan pelanggaran atau menyimpang dari peraturan-peraturan yang terdapat dalam perjanjian waralaba (franchise agreement). Seperti halnya yang terjadi pada pelaksanaan perjanjian waralaba di Pos Indonesia (Persero), sengketa antara para pihak diselesaikan secara musyawarah dan mufakat berdasarkan prinsip win-win solution dan apabila jalan musyawarah tidak tercapai, maka akan diselesaikan lewat jalur Pengadilan di Pengadilan Negeri setempat. Dalam praktek di lapangan para pihak yang terlibat dalam sengketa cenderung mengenyampingkan hukum kontrak (formal) dan doktrin kontrak dengan alasan bahwa pengusaha saling tergantung, hidup dan bekerja dalam jaringan hubungan yang berkesinambungan bukan sebagai kompetitor melainkan sebagai usaha yang saling memberikan manfaat dan keuntungan. Perlindungan hukum yang diberikan oleh Pemerintah melalui aturan-aturan hukum yang dibuatnya, sangat erat kaitannya dengan penegakan hukum (rule of law). Dalam konteks penegakan hukum terhadap bisnis waralaba ini, tentunya sangat ditentukan oleh peran para subyek hukum dalam mendukung berlakunya hukum melalui pemenuhan isi perjanjian, baik itu oleh franchisor maupun franchisee.

Bagaimanapun tegaknya dan terealisasinya isi perjanjian yang disepakati merupakan landasan hukum yang harus dijaga dalam memberikan pelayanan dan kenyamananbagi kelangsungan bisnisnya.

Dapat dikatakan pula bahwa penegakan hukum tidak selalu berhasil, seringkali gangguan terjadi apabila ada ketidakserasian antara nilai, kaidah, dan perilaku. Penegakan hukum bukanlah semata-mata berarti pelaksanaan masingmasing atau pelaksanaan keputusan-keputusan hakim meskipun kecenderungannya adalah demikian, ada sisi yang mesti diperhatikan yakni menciptakan, memelihara, dan mempertahankan kedamaian dan keadilan.

Hal ini sesuai pendapat dari Satjipto Rahardjo yang mengatakan ada interaksi diantara keputusankeputusan hukum dan masyarakat tempat keputusan itu dijalankan nantinya. Oleh karena adanya kebutuhan untuk melakukan penyesuaian sosial yang demikian itulah maka sesuatu norma hukum bisa saja berubah-ubah isinya, tanpa terjadinya perubahan pada peraturan itu sendiri secara formal.

\section{PENUTUP}

\section{Kesimpulan}

1. Peran notaris dalam perjanjian waralaba merupakan suatu perikatan/ perjanjian antara dua pihak dimana semua ketentuannya mengacu pada Kitab Undang - Undang Hukum Perdata yaitu Pasal 1313 KUHPerdata tentang perjanjian, Pasal $1320 \mathrm{KUH}$ Perdata tentang sahnya perjanjian dan ketentuan Pasal 1338 ayat ( 1 ) KUHPerdata tentang asas kebebasan berkontrak. Perjanjian waralaba adalah perjanjian yang tidak bertentangan dengan undang-undang, agama, 
ketertiban umum, dan kesusilaan. Artinya perjanjian itu menjadi undang - undang bagi mereka yang membuatnya, dan mengikat kedua belah pihak.

Perjanjian tersebut bisa dilakukan di bawah tangan dengan mengikuti ketentuan dalam Kitab Undang-Undang Hukum Perdata. Setelah format perjanjian waralaba dibuat dan ditandatangani kedua belah pihak, langkah yang diambil oleh PT. Pos Indonesia (Persero) adalah dengan mencatatkannya di kantor Notaris / waarmerking dimana para pihak yang mengadakan perjanjian tidak perlu hadir berhadapan dengan Notaris. Fungsinya supaya pihak ketiga mengetahui jika perjanjian tersebut telah dibuat.

2. Hambatan dan solusi dalam perjanjian waralaba ini merupakan perjanjian baku timbal balik dimana masing-masing pihak berkewajiban melakukan prestasi. Pelaksanaan perjanjian bisnis waralaba di PT. Pos Indonesia (Persero) Pati berpedoman kepada perundang-undangan dan tunduk kepada Buku III Kitab Undang - Undang Hukum Perdata tentang Perjanjian.

Dalam praktek di lapangan terjadi hambatan yang dilakukan oleh franchisee. Hambatan ini menimbulkan wanprestasi yang berakibat kerugian pada franchisor. Solusi dari tindakan wanprestasi adalah timbulnya hak dari pihak yang dirugikan dalam kontrak tersebut untuk menuntut ganti kerugian kepada pihak yang menyebabkan kerugian. Terhadap kerugian yang harus ditanggung franchisor ini, berlaku perlindungan hukum bagi pihak yang dirugikan seperti yang disebutkan dalam pasal 1267 KUH Perdata.

3. Akibat hukum jika perjanjian waralaba antara PT. Pos Indonesia (Persero) Pati dengan badan usaha perseorangan jika tidak dibuat akta notariel maka melalui jalur musyawarah yang menekankan prinsip win-win solution. Apabila persengketaan tersebut tidak dapat diselesaikan secara musyawarah dan mufakat maka ke dua belah pihak sepakat dan setuju untuk menyelesaikannya dengan memilih domisili di Pengadilan Negeri. Dalam kontrak yang dibuat oleh para pihak, telah ditentukan tempat penyelesaian sengketa, namun dalam kenyataannya peraturan tersebut tidak berlaku karena kedua belah pihak hidup dan bekerja dalam jaringan hubungan yang berkesinambungan. Dengan demikian dapatlah dikatakan bahwa hal-hal yang bersifat formal dan prosedural tidaklah selamanya sesuai dengan tuntutan perkembangan masyarakat terlebih yang berhubungan dengan kegiatan - kegiatan yang bersifat ekonomis.

\section{Saran}

1. Dalam hal ini Pemerintah meberikan sosialisai berkaitan dengan penerima waralaba yaitu berkaitan dengan IMB, izin lingkungan, SIUP dan TDP, Untuk franchisor harus melakukan seleksi ketat terhadap para franchesee/ kandidat yang benar-benar telah terkualifikasi dengan baik ( tidak hanya sekedar modal) dan Melakukan langkah-langkah preventif seperti pembuatan kontrak yang mudah dipahami, meminimalkan celah-celah atau lubang-lubang hukum (loopholes) dari kontrak perjanjian yang bisa digunakan secara sepihak, dan adanya mekanisme kontrol yang memadai.

2. Penerima waralaba sebelum memutuskan untuk membeli hak waralaba harus menyesuaikan dengan karakter diri penerima waralaba itu sendiri, karena format bisnis waralaba harus mengikuti prosedur yang ditentukan pemberi waralaba yang nantinya dirasakan mengekang kreatifitas dan ego penerima waralaba.

3. Notaris Dalam kontrak yang dibuat oleh para pihak, telah ditentukan tempat penyelesaian sengketa, namun dalam kenyataannya peraturan tersebut tidak berlaku karena kedua belah pihak hidup dan bekerja dalam jaringan hubungan yang berkesinambungan. Dengan demikian dapatlah dikatakan bahwa hal-hal yang bersifat formal dan prosedural tidaklah selamanya sesuai dengan tuntutan perkembangan masyarakat terlebih yang berhubungan dengan kegiatan - kegiatan yang bersifat ekonomis maka perlu notaris membuatkan akta notariel bukan hanya di waarmeking dan perlu para pihak yang mengadakan peerjanjian hadir berhadapan dengan Notaris. 


\section{DAFTAR PUSTAKA}

Amir Karamoy, Sukses Usaha Lewat Waralaba, Jurnalindo Aksara Grafika, Jakarta 1996

Abdulkadir Muhammad, 1982. Hukum Perikatan, Alumni, Bandung,

Ahmadi Miru. 2010 Hukum Kontrak dan Perancangan Kontrak. PT. Raja Grafindo Persada: Jakarta.

Bambang Sunggono 2003, Metode Penelitian Hukum, PT Raja Grafindo Persada, Jakarta.

Citra Sayyid Sabiq. 1987 Fiqth Sunnali, Alili Bahasa Oleh Kamaluddin A Marzuki. Jilid 12. PT. al-
Ma'arif. Bandung

Gunawan Widjaja, 2003, Waralaba, PT RajaGrafindo Persada, Jakarta.

Ira Koesoemawati dan Yunirman Rijan, 2009, Kenotaris, Raih Asa Sukses, Jakarta.

Juajir Sumardi, 1995, Aspek-aspek Hukum Franchise dan Perusahaan Transnasional, PT. Citra Aditya Bakti, Bandung.

Komariah, 2008,Hukum Perdata (Edisi Revisi), UMM Press, Malang

Lumban Tobing, 1999, Peraturan Jabatan Notaris, Gelora Aksara Pratama, Jakarta. 